\title{
suPAR, a soluble form of urokinase plasminogen activator receptor, inhibits human prostate cancer cell growth and invasion
}

\author{
M. PICCOLELLA ${ }^{1}$, C. FESTUCCIA ${ }^{2}$, D. MILLIMAGGI ${ }^{2}$, A. LOCATELLI ${ }^{1}$, \\ M. BOLOGNA ${ }^{2}$, M. MOTTA ${ }^{1}$ and D. DONDI ${ }^{1}$ \\ ${ }^{1}$ Department of Endocrinology, Centre for Endocrinological Oncology, University of Milano, Milano; \\ ${ }^{2}$ Department of Experimental Medicine, University of L'Aquila, L'Aquila, Italy
}

Received July 26, 2007; Accepted September 20, 2007

\begin{abstract}
Urokinase-type plasminogen activator (uPA) and its specific membrane receptor (UPAR) control extracellular matrix proteolysis, cell migration, invasion and cell growth in several cancers. The UPAR released from human cancers is detected in blood as soluble uPAR (suPAR). No information is available on the mechanism(s) of action of suPAR on prostate cancer (PCa) cell growth and invasion. In order to clarify this issue, we tested the effect of a treatment with the human recombinant suPAR (comprising amino acids 1-303) on the proliferation, migration and invasion of DU145 cells, a PCa cell line expressing a potent autocrine uPA-uPAR signalling system. The results indicate that suPAR significantly inhibits cell growth, promotes apoptosis and decreases both migration and Matrigel ${ }^{\mathrm{TM}}$ invasion of DU145 cells. The mechanism of action of suPAR seems to be linked to a decrease of ERK and FAK activation. Cleavage of suPAR by chymotripsin reverses these effects. When added to the uPA-negative LNCaP cells, suPAR was ineffective; on the contrary, when LNCaP cells were cultured on fibronectin-coated plates in order to stimulate uPA expression, suPAR significantly decreased cell proliferation. In conclusion, our data suggest that suPAR can function as a potent molecule scavenger for uPA in human PCa cells characterized by high levels of UPA/uPAR as in DU145 cells, while it is ineffective in uPA-deficient LNCaP cells. The molecular mechanism(s) through which suPAR participates in the control of PCa progression may bear relevance for the long-term goal to identify new therapeutic targets aimed at silencing tumours in vivo.
\end{abstract}

\section{Introduction}

Advanced prostate cancer ( $\mathrm{PCa}$ ) morbidity and mortality are strictly correlated with a higher proliferation rate and metastatic

Correspondence to: Dr Donatella Dondi, Department of Endocrinology, Centre for Endocrinological Oncology, University of Milano, Via Balzaretti 9, 20133 Milano, Italy

E-mail: donatella.dondi@unimi.it

Key words: soluble urokinase-type plasminogen activator receptor (suPAR), prostate cancer, metastatic progression progression (1). Little information is available on the molecular mechanism(s) involved in the control of the metastatic properties of PCa cells.

The processes of tissue remodelling associated with cancer invasion and metastasis are controlled by proteolytic enzymes, which participate in the extensive disruption of cell/cell and cell/extra-cellular matrix (ECM) contacts (2). The tumour cellassociated urokinase-type plasminogen activator (PA) system, consisting of the serine protease uPA, its substrate plasminogen, the membrane-bound receptor uPAR, as well as the inhibitors PAI-1/2, plays an important role in these pericellular processes and it is implicated in PCa progression and invasion (3-5). uPA is secreted as an inactive pro-enzyme, which localizes on the cell surface by binding UPAR (6). The human receptor uPAR consists of 3 homologous domains (D1, D2 and D3) linked to the membrane by a glycosylphosphatidylinositol (GPI) anchor at the C-terminus (7). Since the amino-terminal domain (D1) is required for the binding to uPA, all three domains are needed for high affinity binding $(8,9)$.

The presence of the uPA/uPAR system provided by the tumour cells may be sufficient to modulate directional proteolysis through the activation of plasminogen, initiating a proteinase cascade which culminates in metalloproteinase activation and degradation of extracellular matrix proteins (10-13).

UPAR laterally associates with several trans-membrane receptors, including integrins and the EGFR within the same plasma membrane. By regulating the activity of integrins and EGFR, uPAR also participates in the control of extracellular signals controlling cell growth (14).

The uPA/uPAR complex is capable of activating a number of pathways $(15,16)$. In many cell types, when uPA binds to $\mathrm{UPAR}$, it activates signal transduction and protein tyrosine kinases, including focal adhesion kinase (FAK) (17) and extracellular signalling regulated kinase (ERK) $(18,19)$. Otherwise, vitronectin, as another ligand of UPAR, is able to activate distinct cell-signalling pathways from that controlled by uPA such as the small GTPase, Rac1, and thereby regulates downstream factors involved in new actin polymerization $(20,21)$.

Overexpression of components of the uPA-system in nonmetastatic cells enhances metastasis; inhibition of uPA and/or of the $\mathrm{UPA} / \mathrm{uPAR}$ interaction prevents or reduces metastasis in animal models $(22,23)$. Reduced metastasis of transgenic 
mammary cancer is reported in urokinase deficient mice (24). Furthermore, antimetastatic drugs such as GnRH analogues widely used for PCa treatment exhibit not only an antiproliferative effect, but also inhibitory effects on uPA secretion (25).

A soluble form of uPAR (suPAR) lacking the GPI-anchor has also been found both in vivo and in vitro. Intact uPAR is released from the plasma membrane by GPI-specific phospholipase and proteases (26) and may also be generated by alternative splicing of the UPAR mRNA (27). Cleaved UPAR forms are present in several neoplastic cell lines and tissues $(28,29)$. In humans, suPAR, both intact and cleaved, is found in blood, ascitic fluid, tissues and urine of many types of cancer. Measurements of suPAR forms in squamous cell lung cancer (30), colon cancer (31) and breast cancer (32) have prognostic significance, since increased UPAR in blood is correlated with poor prognosis $(33,34)$. However, uPAR has not been shown to be useful in PCa diagnostics $(13,35)$, even if measurements of individual cleaved forms of suPAR contributed significantly to discrimination of men with PCa from those with no evidence of malignancy $(36,37)$. In animal models, suPAR reduces in vivo the growth and metastasis of MDA-MB 231 breast cancer cells and OV-MZ-6\#8 ovarian cancer cells $(38,39)$.

No information has been published so far regarding a possible role of intact suPAR in the mechanisms controlling PCa progression.

To this purpose, we have studied the effect of suPAR on cell growth, migration and invasion of PCa cells; the signalling pathways affected by suPAR, especially in terms of ERK and FAK activation, have been tested. Experiments have been performed on PCa metastatic and androgen-independent DU145, expressing high levels of uPA/uPAR. Moreover, we have tested the effect of suPAR on cell growth of androgendependent LNCaP; in these cells, uPA is not expressed at a sufficient level to establish autocrine uPA/uPAR signalling.

\section{Materials and methods}

Reagents and antibodies. Recombinant human soluble uPAR (suPAR), comprising the amino acids 1-303, was from R\&D Systems, Inc. (Minneapolis, MN). suPAR was dissolved in sterile PBS containing $0.1 \%$ bovine serum albumin to prepare a stock solution of $20 \mu \mathrm{g} / \mathrm{ml}$.

Cleaved suPAR (CsuPAR) was prepared by treating suPAR with $2.0 \mathrm{nM}$ chymotrypsin for $7 \mathrm{~h}$ at $37^{\circ} \mathrm{C}$. The chymotrypsin was inactivated with 1.0 mM PMSF, as described (40). Chymotrypsin and protease inhibitor mixture were from SigmaAldrich (Milano, Italy). Antibodies to ERK1/2, FAK, uPA and uPAR were from Santa Cruz (CA). Horseradish peroxidase conjugated antibodies were from Santa Cruz (CA).

Cell culture. The PCa DU145 and LNCaP cells were obtained from the American Type Culture Collection (Rockville, MD). Cells were routinely grown in RPMI-1640 medium (Biochrom $\mathrm{KG}$, Berlin, Germany), supplemented with $5 \%$ foetal bovine serum (FBS) that was obtained from Gibco BRL, Grand Island, NY), glutamine (2 mM), penicillin (100 IU/ml), and streptomycin $(100 \mu \mathrm{g} / \mathrm{ml})$ in a humidified atmosphere of $5 \%$ $\mathrm{CO}_{2}, 95 \%$ air at $37^{\circ} \mathrm{C}$.
In order to stimulate uPA production, the LNCaP cells were plated in tissue culture wells pre-coated with fibronectin (5 $\mu \mathrm{g} / \mathrm{ml}$, BD Biosciences).

Cell growth studies. DU145 cells, plated in 10-mm dishes in serum-free medium, were treated for $48 \mathrm{~h}$ with suPAR (1.0$10 \mathrm{nM})$. Cells were then harvested and counted by using a haemocytometer. In another series of experiments, $1 \mu \mathrm{Ci} / \mathrm{ml}$ $\left[{ }^{3} \mathrm{H}\right]$ thymidine was added to DU145 and LNCaP cells. DU145 cells, cultured in serum-free medium, were incubated for $24 \mathrm{~h}$ with graded doses of suPAR (1.0-10 nM). Six hours following $\left[{ }^{3} \mathrm{H}\right]$ thymidine addition, cells were washed in PBS and radioactivity was counted in a $\beta$-counter 1600CA TRICARB (Perkin-Elmer).

The results of three separate experiments are presented as the mean \pm SD. Each experimental group was composed of 8 replicates. Statistical analysis was performed by one-way ANOVA followed by Tukey's multiple comparison tests. $\mathrm{p}<0.05$ was considered statistically significant.

FACScan analysis. For FACScan analysis, adherent DU145 cells, pre-treated with suPAR $(10 \mathrm{nM})$ for $24 \mathrm{~h}$ in serum-free medium, were harvested, pooled with the culture supernatant containing the apoptotic cells already detached from the dish and centrifuged. Cells $\left(1 \times 10^{6}\right)$ were washed in PBS, fixed in $70 \%$ ethanol, centrifuged, and re-suspended in DNA staining solution (PBS containing $200 \mathrm{mg} / \mathrm{ml} \mathrm{RNase} \mathrm{A,} 20 \mathrm{mg} / \mathrm{ml}$ propidium iodide plus $0.1 \%$ Triton $\mathrm{X}-100)$. Cells were then stained by incubation at room temperature for $60 \mathrm{~min}$. All cells were then measured on a FACScan flow cytometer (Becton Dickinson, UK) with an argon laser at $488 \mathrm{~nm}$ for excitation and analyzed using Cell Quest software (Becton Dickinson). All the flow cytometric measurements were made using the same instrument settings, and at least 10,000 cells were measured in each sample. A quantifiable peak detected apoptotic cells in the sub-G1 phase corresponding to the red fluorescence light emitted by sub-diploid nuclei of cells; the results were expressed as the percentage of death by apoptosis induced by suPAR treatment. The results of three separate experiments are presented as the mean \pm SD. Each experiment was performed in triplicate. Statistical analysis was performed by one-way ANOVA followed by Tukey's multiple comparison tests. $\mathrm{p}<0.05$ was considered statistically significant.

Migration and invasion assays. Briefly, cell migration assay was performed using a 48-well Boyden chamber (Neuroprobe, Inc) containing $8-\mu \mathrm{m}$ polycarbonate filters (Nucleopore, Concorezzo, Milan, Italy). Filters were coated on one side with $50 \mu \mathrm{g} / \mathrm{ml}$ laminin, rinsed once with PBS, and then placed in contact with the lower chamber containing RPMI-1640 medium. DU145 cells, pre-treated for $48 \mathrm{~h}$ with suPAR (1.0$10 \mathrm{nM})$, were collected and then added in aliquots $(75,000$ cells/50 $\mu \mathrm{l}$ ) to the top of each chamber and allowed to migrate through coated filters for $4 \mathrm{~h}$. At the end of the incubation, the migrated cells attached to the lower membrane surfaces were fixed, stained with Diffquik (Biomap, Italy) and counted at a x40 magnification by standard optical microscopy.

Invasion assay was performed in invasion chambers (Becton Dickinson, Bedford, MA) containing a membrane coated with Matrigel $^{\mathrm{TM}}$. The digestion of Matrigel allowed 
A
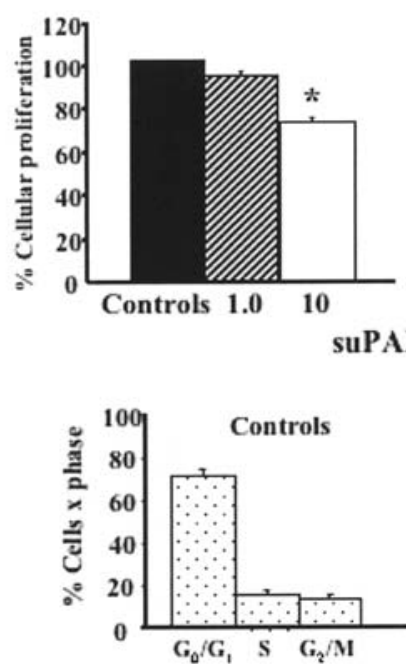

B

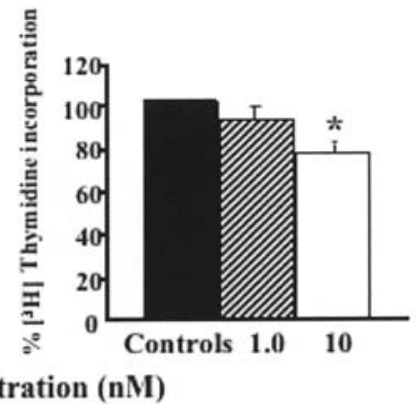

C

D

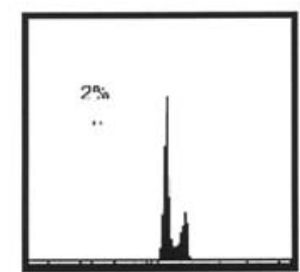

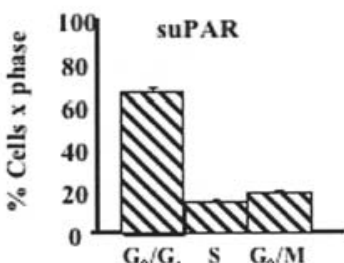

$G_{0} / G_{1} \quad S \quad G_{2} / M$

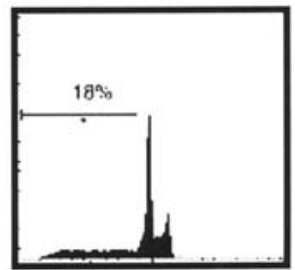

Figure 1. suPAR regulation of cell growth. DU145 cells, cultured in serum-free medium, were treated with suPAR (1.0-10 nM) for 48 h. At the end of the treatments, cells were harvested and counted using a haemocytometer $(\mathrm{A})$. $\left[{ }^{3} \mathrm{H}\right]$ thymidine incorporation on DU145 cells cultured in serum-free medium and incubated for $24 \mathrm{~h}$ with graded doses of suPAR $(1.0-10 \mathrm{nM})$. Cell number is expressed as a percentage of [ $\left.{ }^{3} \mathrm{H}\right]$ thymidine incorporation $(\mathrm{B})$. The results of three separate experiments are presented as the mean \pm SD. Each experimental group was composed of 8 replicates. Cell cycle analysis of DU145 cells treated with suPAR (C and D). The adherent DU145 cells were treated for $24 \mathrm{~h}$ with suPAR (10 $\mathrm{nM})$ in serum-free medium. All cells were then measured on a FACScan flow cytometer with an argon laser at $488 \mathrm{~nm}$ for excitation and analyzed using Cell Quest software. The results were expressed as the percentage of cell death by apoptosis induced by suPAR treatment. Each experiment was performed in triplicate. Statistical analysis was performed by one-way ANOVA followed by Tukey's multiple comparison tests. ${ }^{*} \mathrm{p}<0.05$ vs controls was considered statistically significant.

the migration of cancer cells. Briefly, DU145 cells, pre-treated with suPAR $(1.0-10 \mathrm{nM})$ for $48 \mathrm{~h}$, were collected and $500 \mu \mathrm{l}$ of cell suspension $(75,000$ cells) was added to trans-well inserts with an $8-\mu \mathrm{m}$ pore size coated with Matrigel. In the lower compartment of the invasion chamber $5 \%$ FBS-containing medium was added as a chemo-attractant. After a 22-h incubation period at $37^{\circ} \mathrm{C}$, cells that passed through the Matrigelcoated filter into the bottom wells were fixed, stained with Diffquik (Biomap, Italy) and counted at a x40 magnification by standard optical microscopy.

The results of three separate experiments of migration and invasion are presented as the mean \pm SD. Each experimental group consisted of 12 samples. Statistical analysis was performed by one-way ANOVA followed by Tukey's multiple comparison tests. $\mathrm{p}<0.05$ was considered statistically significant.

The results are expressed as a percentage of migrated cells vs control cells.

Immunoblot analyses. DU145 cells plated in 10-mm dishes in serum-free medium were treated with human recombinant suPAR $(10 \mathrm{nM})$ or CsuPAR (10 $\mathrm{nM})$, as indicated. DU145 cells were harvested in RIPA buffer containing AEBSF $(0.4 \mu \mathrm{g} /$ $\mu \mathrm{l})$, leupeptin $(1 \mu \mathrm{g} / \mu \mathrm{l})$ and pepstatin A $(1 \mu \mathrm{g} / \mu \mathrm{l})$, centrifuged, and washed in PBS. Protein concentration was determined using the Bradford assay. Equal amounts of protein $(50 \mu \mathrm{g})$ were resolved by $10 \%$ SDS-polyacrylamide gel electrophoresis (SDS-PAGE), for $1.5 \mathrm{~h}$ at $110 \mathrm{~V}$. Proteins were blotted using transfer apparatus (BIO-RAD Trans Blot semi-dry). The membrane was washed with $10 \mathrm{mM}$ Tris- $\mathrm{HCl}, 150 \mathrm{mM}$ $\mathrm{NaCl}, 0.1 \%$ Tween-20 (TBST) for $30 \mathrm{~min}$, immersed in a blocking solution with TBST and 5\% (w/v) dry skimmed milk, and then incubated with a diluted solution of the primary antibody at $4^{\circ} \mathrm{C}$ over night.

LNCaP cells were plated in 24-well plates pre-coated or not with fibronectin $(5 \mu \mathrm{g} / \mathrm{ml})$ for $48 \mathrm{~h}$. Cultures were then washed with serum-free medium and incubated for $24 \mathrm{~h}$ with suPAR $(10 \mathrm{nM})$. The cell supernatants, after gel electrophoresis (SDS-PAGE), were subjected to immunoblot analysis to detect uPA.

For ERK1/2, FAK and uPA analyses, we used 1:100 mouse monoclonal antibodies against P-ERK1/2 (E-4, Santa Cruz), 1:1000 rabbit polyclonal antibody against ERK1/2 (K-23, Santa Cruz), 1:100 rabbit polyclonal antibodies against P-FAK (Ser 722, Santa Cruz), 1:100 rabbit polyclonal antibodies against FAK (A-17, Santa Cruz) and 1:100 goat polyclonal antibody against uPA (C-20, Santa Cruz).

After incubation, the membranes were washed and incubated for $1 \mathrm{~h}$ with a secondary antibody conjugated with peroxidase. (1:5000/1:10,000). Immunoreactive bands were visualized using the enhanced chemiluminescence detection 
$\mathbf{A}$

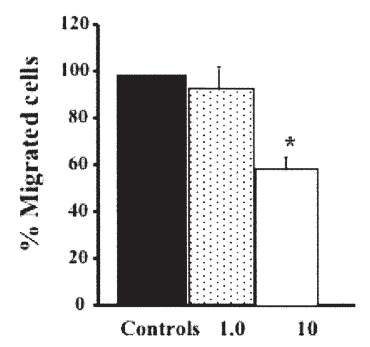

suPAR concentration ( $\mathrm{nM}$ )

Figure 2. Effects of suPAR on cell migration and Matrigel invasion. DU145 cells were treated with suPAR (1.0-10 nM) in serum-free medium for $48 \mathrm{~h}$; cells were then detached, and transferred to a Boyden's chamber and Matrigel invasion chamber. The results of three separate experiments are presented as the mean \pm SD. Each experimental group consisted of 12 samples. Statistical analysis was performed by one-way ANOVA followed by Tukey's multiple comparison tests. ${ }^{*} \mathrm{p}<0.05$ vs controls was considered statistically significant. The results are expressed as a percentage of migrated cells vs control cells.
A

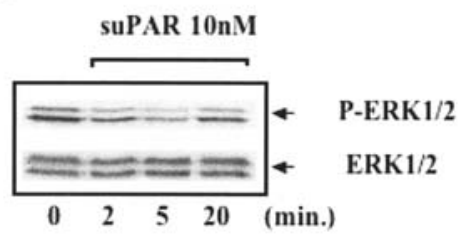

B

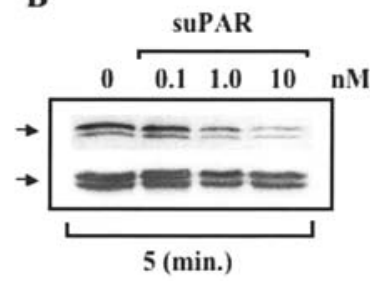

Figure 3. Effects of suPAR on ERK activation. DU145 cells cultured in serum-free medium were treated with $\operatorname{suPAR}(10 \mathrm{nM})$ for the indicated times (A). DU145 cells were treated with graded doses of suPAR (0.1-10 nM) for $5 \mathrm{~min}(\mathrm{~B})$. The cell extracts were subjected to immunoblot analysis to detect phosphorylated and total ERK1/2. Immunoreactive bands were detected at 41-44 $\mathrm{kDa}$. Blots are representative of 3 different experiments.

kit reagents (ECL Plus Western blotting detection system, Amersham Biosciences, UK).

\section{Results}

SUPAR regulation of cell growth. We undertook experiments to examine the potential role of suPAR in regulating cell growth in PCa DU145 cells. First of all, DU145 cells, cultured for $48 \mathrm{~h}$ with suPAR (1.0-10 nM), were harvested and counted using a haemocytometer. As shown in Fig. 1A, suPAR, at the dose of $10 \mathrm{nM}$, inhibited the proliferation of DU145 cells. Moreover, a 24-h treatment with $10 \mathrm{nM}$ suPAR significantly decreased $\left[{ }^{3} \mathrm{H}\right]$ thymidine incorporation of DU145 cells with respect to untreated cells (Fig. 1B). FACScan analysis of DU145 cells treated for $24 \mathrm{~h}$ with $10 \mathrm{nM}$ suPAR indicated a slight accumulation of cells in the G2/M cell cycle phase $(18.94 \pm 1.28 \%)$ with respect to untreated cells $(13.59 \pm 1.67 \%)$ (Fig. 1C) and a decrease in cells in the G0/G1 phase (suPAR treated, 66.19 $\pm 2.32 \%$; controls, $71.33 \pm 2.93 \%$ ); the $S$ phase population was essentially unchanged (suPAR-treated, $14.87 \pm 1.44 \%$; controls, $15.08 \pm 1.85 \%$ ). Moreover, apoptotic cells in the sub-G1 phase were detected in DU145 cells treated with suPAR (Fig. 1D). The results, expressed as the percentage

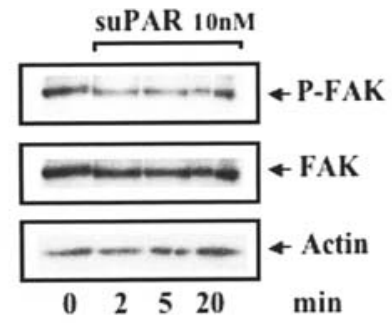

Figure 4. Effects of suPAR on FAK activation. DU145 cells cultured in serum-free medium were treated with suPAR $(10 \mathrm{nM})$ for the indicated times. The cell extracts were subjected to immunoblot analysis to detect phosphorylated and total FAK. An immunoreactive band was detected at $125 \mathrm{kDa}$. The same blots were successively incubated with an anti-actin antibody to normalize FAK levels. Blots are representative of 3 different experiments.
A

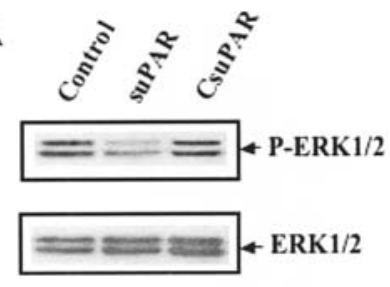

B

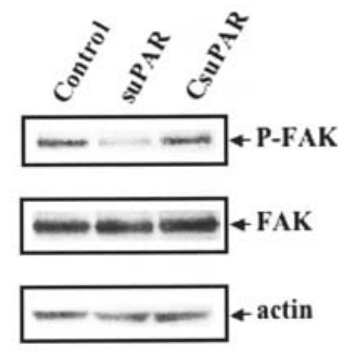

Figure 5. Effect of cleaved suPAR (CsuPAR) on ERK and FAK activation. CsuPAR was prepared by treating suPAR with chymotrypsin $\left(37^{\circ} \mathrm{C}\right.$ for $\left.7 \mathrm{~h}\right)$. DU145 cells, cultured in serum-free medium, were treated with either suPAR $(10 \mathrm{nM})$, or CsuPAR $(10 \mathrm{nM})$ for $5 \mathrm{~min}$. The cell extracts were subjected to immunoblot analysis to detect ERK1/2 (A) and FAK (B) phosphorylation. Blots are representative of 3 different experiments.

of death by apoptosis induced by suPAR treatment, show that suPAR increased the number of apoptotic cells from 2 to $18 \%$.

Effects of SUPAR on cell migration and Matrigel ${ }^{T M}$ invasion. To test the effects of suPAR on DU145 cell migration and invasion, we used haptotaxis assay and Matrigel invasion chamber analysis. Fig. 2A shows that DU145 cells responded to suPAR, decreasing the capacity to migrate in response to laminin used as a haptotactic stimulus. In particular, exposure to $10 \mathrm{nM}$ suPAR reduced the migratory activity of DU145 of $41 \%$.

The effect of suPAR was then evaluated on the ability of DU145 to invade a tridimensional matrix of Matrigel. Fig. 2B indicates that $10 \mathrm{nM}$ suPAR exposure significantly inhibited the invasiveness of DU145 cells (47\% decrease) through the Matrigel barrier.

The effect of suPAR on ERK and FAK activation. To clarify whether suPAR might modify ERK and FAK activation in PCa cells, we performed immunoblotting on extracts of DU145 cells exposed for 2, 5 and $20 \mathrm{~min}$ to $\operatorname{suPAR}(10 \mathrm{nM})$. Fig. 3 demonstrates that, in our experimental conditions, both ERK and FAK were activated in untreated DU145 cells. Moreover, suPAR actually decreased ERK phosphorylation; this effect was clearly evident after 5 min of treatment (Fig. 3A). At the same time of observation, soluble uPAR (1.0-10 nM) was able to decrease, in a dose-dependent manner, ERK phosphorylation; 
$\mathbf{A}$

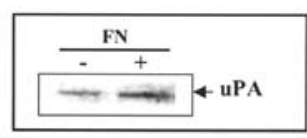

B

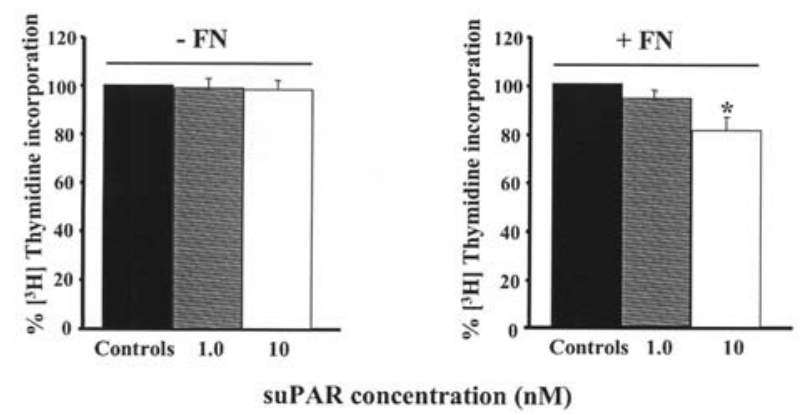

Figure 6. Effect of suPAR on $\left[{ }^{3} \mathrm{H}\right]$ thymidine incorporation of LNCaP cells. LNCaP cells were seeded in 24-well plates pre-coated (C) or not (B) with fibronectin $(5 \mu \mathrm{g} / \mathrm{ml}, \mathrm{FN})$. After $24 \mathrm{~h}$, the cultures were washed with serumfree medium and incubated for $48 \mathrm{~h}$ with suPAR (1.0-10 nM). The cell media were subjected to immunoblot analysis to detect uPA at $33 \mathrm{kDa}$ (A). At the end of the treatments, $\mathrm{LNCaP}$ cells were subjected to $\left[{ }^{3} \mathrm{H}\right]$ thymidine incorporation. Cell number is expressed as a percentage of $\left[{ }^{3} \mathrm{H}\right]$ thymidine incorporation. The results of three separate experiments are presented as the mean \pm SD. Each experimental group was composed of 8 replicates. Statistical analysis was performed by one-way ANOVA followed by Tukey's multiple comparison tests. ${ }^{*} \mathrm{p}<0.05$ vs controls was considered statistically significant.

the inhibition of ERK activation was consistently observed with $10 \mathrm{nM}$ suPAR (Fig. 3B). Then, we studied the effect of treatment for 2, 5, and 20 min with suPAR (10 $\mathrm{nM})$ on FAK phosphorylation in DU145 cells (Fig. 4). Immunoblot analysis of DU145 extracts also evidenced that suPAR produced a decrease of FAK phosphorylation after 2 min of treatment, and the effect was maintained for up to $20 \mathrm{~min}$.

The cleavage of the protease sensitive region of UPAR between D1 and D2 produces a short fragment (D2D3), which no longer binds uPA (41). DU145 cells exposed for $5 \mathrm{~min}$ to suPAR cleaved by chymotrypsin (CsuPAR) did not show the decrease of ERK and FAK phosphorylation previously described after suPAR treatment (Fig. 5A and B).

SUPAR regulation of $\left[{ }^{3} \mathrm{H}\right]$ thymidine incorporation in $L N C a P$ cells. To verify that the mechanism of action of suPAR is linked to its capability to bind UPA, we performed experiments using LNCaP cells that do not express uPA at a sufficient level to establish autocrine uPA/uPAR signalling (42). However, when seeded on fibronectin-coated plates, LNCaP cells secrete detectable levels of uPA (43). In our experimental conditions, LNCaP seeded on fibronectin $(5 \mu \mathrm{g} / \mathrm{ml})$ secreted in the cell culture media higher amounts of uPA with respect to cells plated in standard conditions (Fig. 6A). Then, we measured $\left[{ }^{3} \mathrm{H}\right]$ thymidine incorporation on LNCaP cells plated (Fig. $6 \mathrm{C}$ ) or not (Fig. 6B) on fibronectin and treated for $24 \mathrm{~h}$ with graded doses of suPAR (1.0-10 nM). LNCaP cells grown in standard conditions did not evidence significant effects on $\left[{ }^{3} \mathrm{H}\right]$ thymidine incorporation after suPAR exposure (Fig. 6B), whereas there was a significant and dose-dependent decrease of the proliferation of LNCaP cells when plated on fibronectin-coated wells (Fig. 6C).

\section{Discussion}

The present study was aimed at investigating whether soluble UPAR is able to inhibit proliferation and/or invasion of PCa cancer cells. In particular, we performed experiments on the human prostate cancer cell line DU145, an androgenindependent PCa cell line expressing an efficient UPA-uPAR signalling system $(42,44)$. We report, for the first time, evidence demonstrating that soluble UPAR may antagonize cell growth, promotes apoptosis and decreases both migration and Matrigel invasion of PCa cells.

The exogenous addition of recombinant suPAR significantly decreases, in a dose-dependent manner, cell proliferation and promotes apoptosis in DU145 cells. Since the activation of UPAR by UPA triggers DU145 cell proliferation (reviewed in ref. 14), one possible mechanism of action of suPAR may be related to its capability to bind uPA, subtracting the endogenous serino-protease from its membrane receptor on tumour cells. In accordance with our data, other authors $(38,39,45)$ demonstrated a suppression of in vivo tumour growth and metastasis of both MDA-MB-231 human breast carcinoma and ovarian cancer OV-MZ-6\#8 cells overexpressing suPAR.

The activation of the PA system is known to promote different processes that involve cell migration, which are a prerequisite for cell invasion and the establishment of metastasis. Another biological effect of suPAR reported in the present study on PCa cells was shown by in vitro migration and invasion assays. We demonstrated that soluble uPAR is able to influence the invasive activities of DU145 cells, since it substantially decreases the capacity to migrate in response to a haptotactic stimulus and the ability of the cells to invade a tridimensional matrix of Matrigel.

It has been reported that the UPA/UPAR complex activation is coupled to a number of intracellular pathways including extracellular signalling regulated kinase (ERK). ERK activation occurs in response to UPAR fractional occupancy, accounting for the role of uPAR autocrine signalling in determining the basal level of activated ERK in many cells $(46,47)$. Moreover, elevated focal adhesion kinase (FAK) expression has been observed in different human cancer cell lines with increasing tumorigenic potential (48-51) and FAK was found to be phosphorylated upon uPA binding to UPAR in several cell types (17). Our data sustain the observation that, in DU145 cells, both ERK1/2 and FAK are activated in standard conditions; moreover, the effects of suPAR on the proliferation and migration of DU145 cells may be linked to a decrease of ERK1/2 and FAK phosphorylation.

The cleavage by chymotripsin prevents the inhibitory action of suPAR on ERK1/2 and FAK activation in DU145 cells and suggests different actions for suPAR and CsuPAR; furthermore, it can be suggested that the breaking of suPAR by proteases represents a mechanism by which cancer cells convert an inhibitory molecule (suPAR) into an ineffective compound (CsuPAR). To demonstrate that the action of suPAR in DU145 cells is linked to the capability of suPAR to scavenge uPA, we performed experiments on LNCaP cells. In these PCa cells, uPA is not expressed at a sufficient level to establish autocrine uPA/uPAR signalling and, as a result, suPAR is unable to affect LNCaP cell proliferation. By contrast, when we cultured 
LNCaP cells on fibronectin-coated plates, an experimental condition that stimulated uPA expression (43), suPAR significantly decreased cell growth. Our data are in agreement with the observations of Jo et al (19); these authors reported that, in $\mathrm{uPAR}$-deficient cells ( $\mathrm{UPAR}^{-/}$murine fibroblast or human embryonic kidney 293 cells), both suPAR and CsuPAR function as a partial signalling agonist that activates ERK. On the contrary, in cells with a potent autocrine uPA-uPAR signalling system (MDA-MB 231 breast cancer cells) suPAR decreased ERK activation and inhibited proliferation, while CsuPAR was ineffective.

In accordance with the findings of other authors $(19,38,39,45,52)$, we propose that suPAR produces different effects on PCa cell proliferation depending on the expression of the endogenous uPA/uPAR system; moreover, we suggest that intact suPAR may scavenge uPA and prevent uPA binding to membrane-anchored UPAR, producing a decrease in the level of activated ERK and FAK in PCa cells.

Prolonged uPAR suppression produces tumour cell 'dormancy', a dormant state during which tumour cells are present but not seemingly biologically or clinically active (reviewed in ref. 53). An increase of uncleaved suPAR able to bind endogenous uPA may be important to control proliferation and migration of cancer cells.

Preliminary studies performed in our laboratory suggest that drugs currently used for the therapeutic treatment of PCa, such as GnRH analogues, seem to counteract the effect of endogenous uPA through the increase of soluble UPAR in the conditioned media of DU145 cells (unpublished data). Even if further studies are needed to clarify the role of suPAR in controlling PCa growth and invasion, the molecular mechanism through which suPAR participates in the biology of advanced PCa cells evidenced in our studies by mechanisms unrelated to plasminogen activation, is novel and entirely untested and may bear relevance for the long-term goal to identify new therapeutic targets aimed to trigger tumour dormancy in vivo.

\section{Acknowledgments}

This study was supported by grants from the EU Marie Curie Training Program 2005, FIRST 2005.

\section{References}

1. Gittes RF: Carcinoma of the prostate. N Engl J Med 324: 236-245, 1991

2. Dano K, Behrendt N, Hoyer-Hansen G, Johnsen M, Lund LR, Ploug $\mathrm{M}$ and Romer J: Plasminogen activation and cancer. Thromb Haemost 93: 676-681, 2005.

3. Achbarou A, Kaiser S, Tremblay G, Ste-Marie LG, Brodt P, Goltzman D and Rabbani SA: Urokinase overproduction results in increased skeletal metastasis by prostate cancer cells in vivo. Cancer Res 54: 2372-2377, 1994.

4. Miyake H, Hara I, Yamanaka K, Gohji K, Arakawa S and Kamidono S: Elevation of serum levels of urokinase-type plasminogen activator and its receptor is associated with disease progression and prognosis in patients with prostate cancer. Prostate 39: 123-129, 1999.

5. Sheng S: The urokinase-type plasminogen activator system in prostate cancer metastasis. Cancer Metastasis Rev 20: 287-296, 2001.

6. Dano K, Andreasen PA, Grondahl-Hansen J, Kristensen P, Nielsen LS and Skriver L: Plasminogen activators, tissue degradation, and cancer. Adv Cancer Res 44: 139-266, 1985.
7. Behrendt N, Andersen J and Rossen K: Intestinal ganglioneuromatosis - a rare cause of chronic diarrhea. Ugeskr Laeger 160: 7139-7140, 1998.

8. Ploug M: Structure-function relationships in the interaction between the urokinase-type plasminogen activator and its receptor. Curr Pharm Des 9: 1499-1528, 2003.

9. Llinas P, Le Du MH, Gardsvoll H, Dano K, Ploug M, Gilquin B, Stura EA and Menez A: Crystal structure of the human urokinase plasminogen activator receptor bound to an antagonist peptide. EMBO J 24: 1655-1663, 2005.

10. Stephens RW, Pollanen J, Tapiovaara H, Leung KC, Sim PS, Salonen EM, Ronne E, Behrendt N, Dano K and Vaheri A: Activation of pro-urokinase and plasminogen on human sarcoma cells: a proteolytic system with surface-bound reactants. J Cell Biol 108: 1987-1995, 1989

11. Estreicher A, Muhlhauser J, Carpentier JL, Orci L and Vassalli JD: The receptor for urokinase type plasminogen activator polarizes expression of the protease to the leading edge of migrating monocytes and promotes degradation of enzyme inhibitor complexes. J Cell Biol 111: 783-792, 1990.

12. Gyetko MR, Hsu CH, Wilkinson CC, Patel S and Young E: Monocyte 1 alpha-hydroxylase regulation: induction by inflammatory cytokines and suppression by dexamethasone and uremia toxin. J Leukoc Biol 54: 17-22, 1993.

13. Andreasen PA, Kjoller L, Christensen L and Duffy MJ: The urokinase-type plasminogen activator system in cancer metastasis: a review. Int J Cancer 72: 1-22, 1997.

14. Mazzieri R and Blasi F: The urokinase receptor and the regulation of cell proliferation. Thromb Haemost 93: 641-646, 2005.

15. Resnati M, Guttinger M, Valcamonica S, Sidenius N, Blasi F and Fazioli F: Proteolytic cleavage of the urokinase receptor substitutes for the agonist-induced chemotactic effect. EMBO J 15: 1572-1582, 1996.

16. Mirshahi SS, Lounes KC, Lu H, Pujade-Lauraine E, Mishal Z, Benard J, Bernadou A, Soria C and Soria J: Defective cell migration in an ovarian cancer cell line is associated with impaired urokinase-induced tyrosine phosphorylation. FEBS Lett 411: 322-326, 1997.

17. Kjøller L: The urokinase plasminogen activator receptor in the regulation of the actin cytoskeleton and cell motility. Biol Chem 383: 5-19, 2002

18. Jo M, Thomas KS, Marozkina N, Amin TJ, Silva CM, Parsons SJ and Gonias SL: Dynamic assembly of the urokinase-type plasminogen activator signaling receptor complex determines the mitogenic activity of urokinase-type plasminogen activator. J Biol Chem 280: 17449-17457, 2005.

19. Jo M, Thomas KS, Wu L and Gonias SL: Soluble urokinasetype plasminogen activator receptor inhibits cancer cell growth and invasion by direct urokinase-independent effects on cell signaling. J Biol Chem 278: 46692-46698, 2003.

20. Kjoller L and Hall A: Rac mediates cytoskeletal rearrangements and increased cell motility induced by urokinase-type plasminogen activator receptor binding to vitronectin. J Cell Biol 152: 1145-1157, 2001.

21. Ma Z, Thomas KS, Webb DJ, Moravec R, Salicioni AM, Mars WM and Gonias SL: Regulation of Rac1 activation by the low density lipoprotein receptor-related protein. J Cell Biol 159: 1061-1070, 2002 .

22. Sidenius $\mathbf{N}$ and Blasi F: The urokinase plasminogen activator system in cancer: recent advances and implication for prognosis and therapy. Cancer Metastasis Rev 22: 205-222, 2003.

23. Margheri F, D'Alessio S, Serrati S, Pucci M, Annunziato F, Cosmi L, Liotta F, Angeli R, Angelucci A, Gravina GL, Rucci N, Bologna M, Teti A, Monia B, Fibbi G and Del Rosso M: Effects of blocking urokinase receptor signaling by antisense oligonucleotides in a mouse model of experimental prostate cancer bone metastases. Gene Ther 12: 702-714, 2005.

24. Almholt K, Lund LR, Rygaard J, Nielsen BS, Dano K, Romer J and Johnsen M: Reduced metastasis of transgenic mammary cancer in urokinase-deficient mice. Int J Cancer 113: 525-532, 2005.

25. Dondi D, Festuccia C, Piccolella M, Bologna M and Motta M: $\mathrm{GnRH}$ agonists and antagonists decrease the metastatic progression of human prostate cancer cell lines by inhibiting the plasminogen activator system. Oncol Rep 15: 393-400, 2006.

26. Wilhelm OG, Wilhelm S, Escott GM, Lutz V, Magdolen V, Schmitt M, Rifkin DB, Wilson EL, Graeff $\mathrm{H}$ and Brunner G: Cellular glycosylphosphatidylinositol-specific phospholipase D regulates urokinase receptor shedding and cell surface expression. J Cell Physiol 180: 225-235, 1999. 
27. Pyke C, Eriksen J, Solberg H, Nielsen BS, Kristensen P, Lund LR and Dano K: An alternatively spliced variant of mRNA for the human receptor for urokinase plasminogen activator. FEBS Lett 326: 69-74, 1993

28. Solberg H, Romer J, Brunner N, Holm A, Sidenius N, Dano K and Hoyer-Hansen G: A cleaved form of the receptor for urokinasetype plasminogen activator in invasive transplanted human and murine tumors. Int J Cancer 58: 877-881, 1994.

29. Piironen T, Laursen B, Pass J, List K, Gardsvoll H, Ploug M, Dano K and Hoyer-Hansen G: Specific immunoassays for detection of intact and cleaved forms of the urokinase receptor. Clin Chem 50: 2059-2068, 2004.

30. Pedersen H, Brunner N, Francis D, Osterlind K, Ronne E, Hansen HH, Dano K and Grondahl-Hansen J: Prognostic impact of urokinase, urokinase receptor, and type 1 plasminogen activator inhibitor in squamous and large cell lung cancer tissue. Cancer Res 54: 4671-4675, 1994.

31. Ganesh S, Sier CF, Heerding MM, Griffioen G, Lamers CB and Verspaget HW: Urokinase receptor and colorectal cancer survival. Lancet 344: 401-402, 1994.

32. Grondahl-Hansen J, Peters HA, van Putten WL, Look MP, Pappot H, Ronne E, Dano K, Klijn JG, Brunner N and Foekens JA: Prognostic significance of the receptor for urokinase plasminogen activator in breast cancer. Clin Cancer Res 1: 1079-1087, 1995.

33. Sier CF, Stephens R, Bizik J, Mariani A, Bassan M, Pedersen N, Frigerio L, Ferrari A, Dano K, Brunner N and Blasi F: The level of urokinase-type plasminogen activator receptor is increased in serum of ovarian cancer patients. Cancer Res 58: 1843-1849, 1998.

34. Stephens RW, Nielsen HJ, Christensen IJ, Thorlacius-Ussing O, Sorensen S, Dano K and Brunner N: Plasma urokinase receptor levels in patients with colorectal cancer: relationship to prognosis. J Natl Cancer Inst 91: 869-874, 1999.

35. Duffy MJ: Urokinase-type plasminogen activator: a potent marker of metastatic potential in human cancers. Biochem Soc Trans 30: 207-210, 2002.

36. Piironen T, Haese A, Huland H, Steuber T, Christensen IJ, Brunner N, Dano K, Hoyer-Hansen G and Lilja H: Enhanced discrimination of benign from malignant prostatic disease by selective measurements of cleaved forms of urokinase receptor in serum. Clin Chem 52: 838-844, 2006.

37. Steuber T, Vickers A, Haese A, Kattan MW, Eastham JA, Scardino PT, Huland $\mathrm{H}$ and Lilja H: Free PSA isoforms and intact and cleaved forms of urokinase plasminogen activator receptor in serum improve selection of patients for prostate cancer biopsy. Int J Cancer 120: 1499-1504, 2007.

38. Kruger A, Soeltl R, Lutz V, Wilhelm OG, Magdolen V, Rojo EE, Hantzopoulos PA, Graeff H, Gansbacher B and Schmitt M: Reduction of breast carcinoma tumor growth and lung colonization by overexpression of the soluble urokinase-type plasminogen activator receptor (CD87). Cancer Gene Ther 7: 292-299, 2000.

39. Lutz V, Reuning U, Kruger A, Luther T, von Steinburg SP, Graeff H, Schmitt M, Wilhelm OG and Magdolen V: High level synthesis of recombinant soluble urokinase receptor (CD87) by ovarian cancer cells reduces intraperitoneal tumor growth and spread in nude mice. Biol Chem 382: 789-798, 2001.
40. Behrendt N, Ploug M, Patthy L, Houen G, Blasi F and Dano K: The ligand-binding domain of the cell surface receptor for urokinase-type plasminogen activator. J Biol Chem 266: 7842-7847, 1991

41. Mazzieri R, D'Alessio S, Kenmoe RK, Ossowski L and Blasi F: An uncleavable uPAR mutant allows dissection of signaling pathways in uPA-dependent cell migration. Mol Biol Cell 17: 367-378, 2006.

42. Festuccia C, Dolo V, Guerra F, Violini S, Muzi P, Pavan A and Bologna M: Plasminogen activator system modulates invasive capacity and proliferation in prostatic tumor cells. Clin Exp Metastasis 16: 513-528, 1998.

43. Pentyala SN, Whyard TC, Waltzer WC, Meek AG and Hod Y: Androgen induction of urokinase gene expression in $\mathrm{LNCaP}$ cells is dependent on their interaction with the extracellular matrix. Cancer Lett 130: 121-126, 1998.

44. Lyon PB, See WA, Xu Y and Cohen MB: Diversity and modulation of plasminogen activator activity in human prostate carcinoma cell lines. Prostate 27: 179-186, 1995.

45. Magdolen V, Kruger A, Sato S, Nagel J, Sperl S, Reuning U, Rettenberger P, Magdolen U and Schmitt M: Inhibition of the tumor-associated urokinase-type plasminogen activation system: effects of high-level synthesis of soluble urokinase receptor in ovarian and breast cancer cells in vitro and in vivo. Recent Results Cancer Res 162: 43-63, 2003.

46. Aguirre Ghiso JA, Kovalski K and Ossowski L: Tumor dormancy induced by downregulation of urokinase receptor in human carcinoma involves integrin and MAPK signaling. J Cell Biol 147: 89-104, 1999.

47. Liu D, Aguirre Ghiso J, Estrada Y and Ossowski L: EGFR is a transducer of the urokinase receptor initiated signal that is required for in vivo growth of a human carcinoma. Cancer Cell 1: 445-457, 2002

48. Fox GL, Rebay I and Hynes RO: Expression of DFak56, a Drosophila homolog of vertebrate focal adhesion kinase, supports a role in cell migration in vivo. Proc Natl Acad Sci USA 96: 14978-14983, 1999

49. Judson PL, He X, Cance WG and Van Le L: Overexpression of focal adhesion kinase, a protein tyrosine kinase, in ovarian carcinoma. Cancer 86: 1551-1556, 1999.

50. Owens LV, Xu L, Dent GA, Yang X, Sturge GC, Craven RJ and Cance WG: Focal adhesion kinase as a marker of invasive potential in differentiated human thyroid cancer. Ann Surg Oncol 3: 100-105, 1996.

51. Tremblay L, Hauck W, Aprikian AG, Begin LR, Chapdelaine A and Chevalier S: Focal adhesion kinase (pp125FAK) expression, activation and association with paxillin and p50CSK in human metastatic prostate carcinoma. Int J Cancer 68: 164-171, 1996.

52. Wilhelm O, Weidle U, Hohl S, Rettenberger P, Schmitt M and Graeff $\mathrm{H}$ : Recombinant soluble urokinase receptor as a scavenger for urokinase-type plasminogen activator (uPA). Inhibition of proliferation and invasion of human ovarian cancer cells. FEBS Lett 337: 131-134, 1994.

53. Laufs S, Schumacher J and Allgayer H: Urokinase-receptor (uPAR): an essential player in multiple games of cancer: a review on its role in tumor progression, invasion, metastasis, proliferation/ dormancy, clinical outcome and minimal residual disease. Cell Cycle 5: 1760-1771, 2006. 